\title{
遺伝的アルゴリズムを用いた有効画像特徵量学習による物体認識
}

\begin{tabular}{|c|c|c|c|}
\hline 学生員 & 後藤 & 邦博 & (岐阜大学) \\
\hline 正 員 & 斉藤 & 文彦 & (岐阜大学) \\
\hline 員 & 山本 & 和彦 & (岐阜大学) \\
\hline
\end{tabular}

\section{Object Recognition by Learning Effective Image Features Using Genetic Algorithm}

Kunihiro Goto (Gifu University), Fumihiko Saitoh (Gifu University), Kazuhiko Yamamoto (Gifu University)

\begin{abstract}
This paper proposed a method to recognize the kind of an object and to determine the location of the object in a gray-scaled image. The kind, location and pose of an object are unknown under the general environment. In the object recognition, typical image features that can represent the characteristics of an object must be used. But it is generally difficult to determine effective image features for object recognition. Therefore, the genetic algorithm is applied to determine the combination of effective image features and their weights automatically in the proposed method. The relative weights of effective image features are determined in the candidates of general image features. The weights of the candidates of image features are represented as an individual chromosome. An individual fitness is evaluated by the discriminant analysis using the total difference of image features between the area including an object and other areas. The experimental results show that the combination of the effective image features and their weights were determined automatically and the objects were recognized successfully using the combination.
\end{abstract}

キーワード：遺伝的アルゴリズム, 物体認識, 特徽量学習, 判別分析法

Keywords: genetic algorithm, object recognition, features learning, discriminant analysis

\section{1.はじめに}

我々の周辺環境には, 日常の生活に必要な多くの物品が存 在し，これらの物品を利用するために，視覚によって各種の 物品の種類を判別し，また，位置を確認している．将来，画 像処理技術を用いて，人間が円滑に行動するための支援シス テムを実現するためには，各種の物品の種類と位置を画像処 理によって認識する技術が必要と考えられる ${ }^{(11)(13)}$.

本論文では，浱淡画像の中から，複数の対象物体の種類を 判別し，また，画像内におけるこれらの物体の位置を検出す るための手法を提案する，画像内から，特定の対象物体を発 見するためには，その物体の種類を識別し，位置を求める必 要がある．本論文では，指定した対象物体を画像内から検出 する処理を認識と呼ぶことにする，一般的な環境下では，認 識すべき物体の種類，位置，および姿勢は不定であるため， これらの変化に対応できる手法が必要となる，また，認識す ベき対象物体にとって背景ノイズとなる無関係な物体が雑 然と存在している場合が多いため，対象物体とシーンの他所 とを正確に識別することが可能な手法が必要となる．濃淡画 像内から各種の対象物体を認識する場合，その対象物体に特 有な特徽量を用いた認識手法が有効と考えられる。しかし， 対象物体によって，一般的に認識に有効な特徽量の種類や数， および各特徴量の重みは異なる，従って，様々な物体に対応 可能な認識システムを構筑するためには,これら認識に有効 な特徽量を自動的に学習する手法が求められる。
本研究では, 物体の種類や管が弯化しても追従可能な認 識システムを構策するために，遺伝的アルゴリズム(GA： Genetic Algorithm) ${ }^{(1)-(4)}$ を用い, 複数の特徽量候補の中から, 対象物体が持つ特有の画像特徴量を自動的に選択し，各特徽 量の重みを決定する. 各々の特徴量候補の重みを個体の染色 体によって表現し, 対象物体とシーンの他所との特徽量の相 違から各個体の適応度を求める，GA を用いることによって， 物体ごとに認識に有効な特徽量とその重みが自動的に設定 され，また，その特徴量に関する学習結果を用いて各種の物 体の認識が可能であることを実験によって示す．

\section{2. 従来の物体認識手法}

一般的な浱淡画像内から，特定の対象物体を認識する方法 としては, テンプレートマッチングが簡便かつ代表的な手法 である(5)ィ(7). しかし，对象物体は，テンプレートに対して正 立していることが条件であり，また，2 次元的な位㯰変化に しか対応できないという制限がある。

次に，モデルベースマッチングによる物体認識手法 ${ }^{(8)-(13)}$ が提案されている．モデルベースマッチングは，物体の姿勢 変化の影響を受け難い適切な特徽量を使用することによっ て，3 次元的な姿勢変化一の対応も可能となる. しかし，一 般的に，対象となる物体の認識に有効な特徽量は，人間が明 示的に与える必要がある.ところが，物体から得ることので きる画像特徵量は多種であるため，認識に有効な特徵量の選 択作業は，その物体に対する知識や試行錯誤が必要となる。 
The candidates of image features

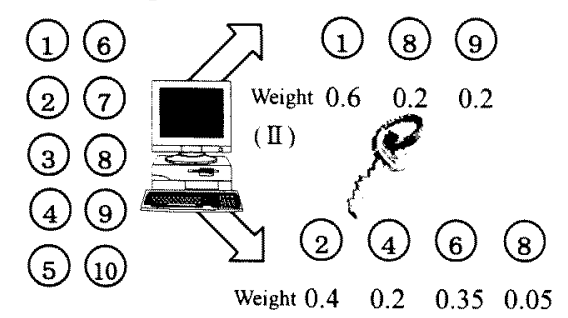

図 1 有効画像特徽量学習

Fig.1 Learning effective image features

また,このような作業を計算機によって実行しようとする場 合，選択すべき特徴量の種類および数が不定であるため，適 切な特徴量を選択するためには, 膨大な計算コストを要する ことが問題となる. 更に, 物体の種類が変化した場合は, 再 度特街量を設定する必要が生じる。

他の物体認識手法としては，工業用部品を対象に，エッジ 情報から得られる楾分と円弧の特徵を用いた手法が提案さ れているが(11)，物体の形状特徽を表現する図形の種類が限定 されているため,より一般的な物体認識に適用する場合, 沉 用性に欠ける可能性があると考えられる.

本論文で提案する手法では，GA を用いて対象物体の認識 に有効な特徴量を選択し, 更に, 各特徴量の重みも決定する. 特徴量を GAによって選択する研究としては, 医用画像にお ける領域分割人の適用例 ${ }^{(14)}$ が報告されているが, 特徴量の重 みに関しては考慮されていない，本手法では，GAにより， 特徽量の種類だけではなく，特徴量間の重みも自動設定する.

\section{3、GAによる特幑量学習}

図 1 は, 本手法における特徵量学習の例を示す.ここでは, (1)〜10までの 10 種類の特徵量候補の中から，物体(I)および 物体(II)の認識に有効な特徽量と各特徽量の重みを設定する ことを考える．例えば，物体(I)では，(1)，(8)，(9)が有効な 特徴量として選択され，それぞれ 0.6，0.2，0.2の重みが設定 される，また物体(I)では，(2)，(4)，(6)，(8)が有効な特徴量 として選択され，それぞれ 0.4，0.2，0.35，0.05の重みが設 定される.一般的に, 各種の物体の認識に有効な特徴量を明 示的に決定することは容易ではない，上記のように，多くの 特徽量候補の中から，ある物体の認識に有効な特徽量を選択 し，またその特徵量の重みを決定したい場合，その解候補は 起大な探索空閒内に存在することになる. 本手法では, 認識 に有効な特徵量とその重みを効率的に設定するために，大局 的な解探索能力に優れている GA を用いる(1)-(4).

GA を具体的な課題に適用するためには，個体の染色体の 表現方法, 適応度の評価方法, 各種の遺伝的操作を設定する 必要がある. また, 本手法では, 複数の特徴量による物体認 識を行うため, 特徵量候補の設定も重要な要件となる，以下 に，GAによる特徵量学習手法について，具体的に述べる.

\section{1 特街青候補の設定}

画像から得られる特徵量は多いが, これらの中から, 幅広
い種類の物体の認識に適用でき，しかも各物体に特有な特徵 を表現できる画像特徽量を候補に挙げることが重要となる。

物体認識において，物体形状を表す画像情報は，認識に有 効な特徵量のひとつと考えられる，そこで，物体形状を表す 画像情報として, エッジ画素間の位置関倸や各エッジ画素に おける 2 次元的な方向成分から得られる特徽量を多く候補と して挙げる. また, より大局的な情報として, エッジ方向の 分布を表すヒストグラムから得られる特徴量も候補とする. 更に, 画像の港淡情報から得られる特徵量も物体認識に重要 と考えられる.ここでは，エッジおよび濃淡情報に関する代 表的な特徴量として, 計 12 種類を挙げることにする. 特徴 量は, 画像から切り出された定形の矩形内で求める. 矩形の 切り出し方法については 3.3 節で具体的に述べる.

以下に，それぞれの特徵量候補について説明する．なお， エッジ画像とは，濃淡画像に対して Prewitt オペレータを実

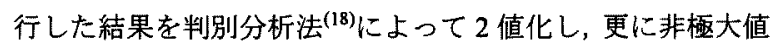

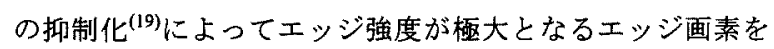
抽出した結果画像とする，また，エッジ方向の分布を表すヒ ストグラムでは, エッジ方向 $\phi$ と $\phi+\pi$ は同一方向と見なし, 方向角度に関する分解能は 90 , また, 各方向角度に関する出 現率は，全体で 1 となるように正規化を施している. 以下に 示す特徽量候補の(a)から(i)までは物体の形状を表すための 特徵量，(j)と(k)は濃淡情報に関する特徴量である.

(a) 曲率分散

例えば键のように，曲線と直線の入り混じった輪郭を持つ 物体では，エッジにおける曲率のばらつき具合が大きくなる と考えられる.そこで, 物体の大局的な形状を表す情報とし て, エッジ部分における曲率の分散值を特徴量候補として挙 げることにする. 曲率は, 注目するエッジ点周辺のエッジ方 向の標準偏差として求め, 画像全体における曲率の分散値を 特徵量候補とする.

(b) エントロピー(15),(16)

全体に丸みを帯びた物体では，輪郭部分のエッジ方向が全 方向に向く傾向が強いので, エッジ方向の分布を表すヒスト グラムのエントロピーは大きくなる，そこで，次式によって 求められるエントロピーの值を特徴量候補とする.

$$
E=-\sum_{i=1}^{90} p(l) \log _{90} p(l)
$$

ここで, $p(l)$ は，エッジ方向の分布を表すヒストグラムの $l$ 番目のデータ值を意味する.

(c) エネルギー(15)

全体の形状が四角形や三角形のような角張った物体では, エッジ方向はある一定の方向に偏るので, エッジ方向の分布 を表すヒストグラムのエネルギーは大きくなる，そこで，次 式で求められるエネルギーの值を特徴量候補とする。

$$
G=\sum_{i=1}^{90} p^{2}(l)
$$

(d),(e),(f) ピーク数

物体の輪郭形状を知る手がかりとして，エッジ方向の分布 を表すヒストグラムにおけるピーク数がある，例えば，正方 


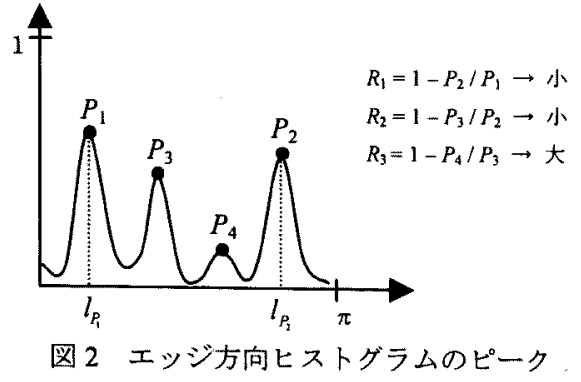

Fig.2 Peaks of edge direction histogram

形の物体ではピーク数は 2, 三角形の物体ではピーク数は 3 となる．ピーク数は，ある程度の長さを持った輪部線をグル 一プ化した数を表すことになる．多くの物体では，ヒストグ ラムのピークとして表れる線分の本数はそれほど多くない と考えられるので，図 2 に示すように，上位の值を持つ4つ のピークを検出し，各ピーク值を $P_{1}, P_{2}, P_{3}, P_{4}$ とする. そし て，各ピーク值の差巽を表す次の各值を求める。

$$
\begin{aligned}
& R_{1}=1-P_{2} / P_{1} \\
& R_{2}=1-P_{3} / P_{2} \\
& R_{3}=1-P_{4} / P_{3}
\end{aligned}
$$

$R_{i}$ の値が大きいほど,つまり隣り合うピーク值の差異が大き

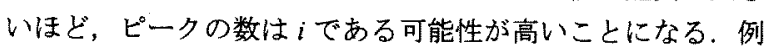
えば，図 2 の場合，実際のピークは， $P_{1}, P_{2}, P_{3}$ のつと考 えられる. この時, (3)式の $R_{1}, R_{2}$ の值は小さいのに対し， $R_{3}$ の值は大きい，つまり，ピーク数が 3 であることを表してい る.このように，(3)式を評価することによって，ヒストグラ ムのピーク数を求めることができる.ここでは，各々のピー ク数を表す尺度として， $R_{1}, R_{2}, R_{3}$ の各值を特街量の候補(各々， (d) ピーク 1，(e)ピーク 2，(f)ピーク 3)上する。

(g) 直角度

次に，エッジ方向の分布を表すヒストグラムにおけるピー ク間の距離も重要な特徵量と考えられる. 例えば, 全体の形 が長方形のようにすべての角が直角である物体の場合， 2 組

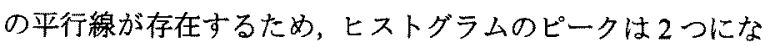
る.このような物体では，エッジ方向の分布を表すヒストグ ラムの第 1 と第 2 のピーク間距離仙，ほぼ 90 度になる.こ こでは, 2 つのピーク $P_{1}, P_{2}$ がそれぞれヒストグラムの $l_{P 1}, l_{P 2}$ 番目の要素のデータ值である時, 次式によるピーク間距離 $T$ を特徵量候補として挙げることにする.

$$
T=1-\left\{|45-| p\left(l_{P_{1}}\right)-p\left(l_{P_{2}}\right)|| / 45\right\}
$$

なお, 0 から $\pi$ までのエッジ方向の分解能を 90 に設定したた め, 上式では 90 度を表す定数が 45 となっている。

(h) エッジ長

形状の大きな物体，あるいは輪郭形状が複雑である物体は， 一般的にエッジ部分が長くなるため, エッジ画素の数が多く なる．このような対象物体を表す特徽量候補として, 次式に 示すエッジ長 $L$ を挙げることにする.

$$
L=1-1 / N_{e}
$$

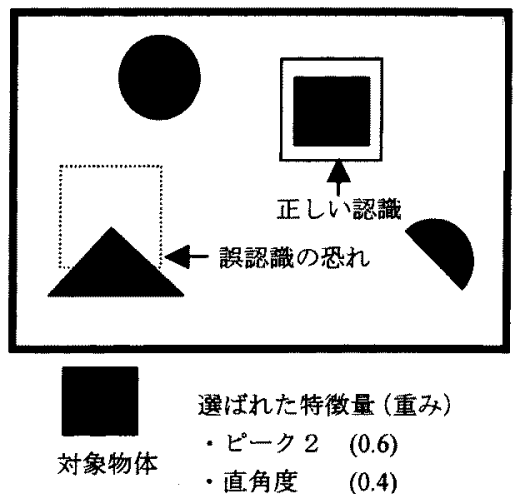

図 3 誤認識の例

Fig.3 Example of wrong recognition

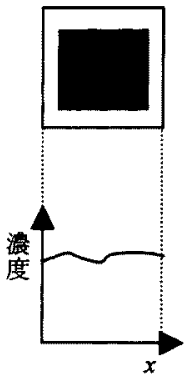

(i) 正しい認㦷

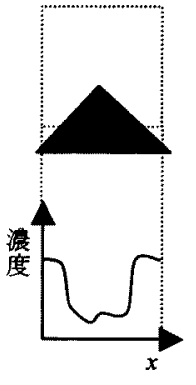

（ii）誤認識
図 4 矩形枠上の濃度分布

Fig.4 Distribution of brightness on frames of rectangles ここで, $N_{e}$ は矩形内に含まれるエッジ画素の数である.

(i) 距離分散

物体の輪郭部分の一部が大きく䆶んでいる場合，物体の重 心から輪郭を表すエッジまでの距離の分散は大きくなると 考えられる.このような物体では，すべてのエッジ画素の重 心位置から各エッジ画素までの距離の分散値が大きくなる ため,この分散値を特徵量候補として挙げることにする.

(j),(k) 浱淡情報 ${ }^{(15)-(17)}$

以上に述べた(a)から(i)は，す心゙て物体形状に関する特徴量 である.しかし，このような形状特徴だけでは，物体固有の 特徴を充分に表現できない場合があると考えられる。そこで， 画像内の濃淡情報から得られる特徴として, 濃淡ヒストグラ ムから得られるエネルギーと分散值(それぞれ，(j)濃度エネル ギー, (k)濃度分散)を特徵量の候補として挙げることにする。 (l) 矩形枠上の濃度分散

以上に述べた $(\mathrm{a})$ から $(\mathrm{k})$ までの特徵量を用いて認識を行う 場合，目的とする物体全体を囲む領域から得られる特徵量と， シーン内における他物体の一部，あるいは目的とする物体の 一部を含む画像領域から得られる特徴量が類似する場合が あり、これらが誤認識の原因となりえる. 図3は,このよう な誤認が発生する例を示す。この場合，対象物体として，正 方形の認識に有効な特徴量をピーク 2 かつ直角度と学習した が, 同じピーク 2 かつ直角度の特徽を持つ点線の矩形で囲ま れた直角三角形の一部を誤認識する危険性がある。このよう な證認を回避するために, 次の特徽量を加える. 図 4(i)は， 


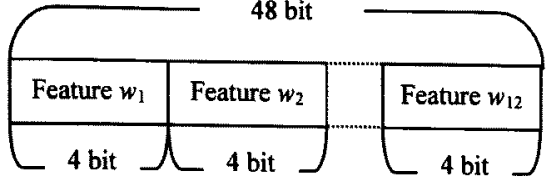

図 5 染色体の表現方法

Fig.5 Representation of chromosome

対象物体を囲む矩形の下辺上の濃度変化を示しているが，矩 形内に物体全体が収まっている場合は，矩形枠上の濃度変化 は比較的小さいと考えられる.一方，矩形内に物体の一部だ けが含まれる場合は，図 4 (ii) に示すように，矩形の枠上に 物体が存在するため, 矩形の辺上を走査すると大きな浱度変 化が観測される.すなわち, 矩形枠上の浱度変化の状態から， 矩形内に物体が収まっているか否かを判定できると考えら れる. そこで, 次式によって求められる矩形の枠上に位置す る全画素の浱度の標準编差を特徴量の候補とする.

$$
Q=1-\sqrt{\sum_{i, j \in V}\left\{f(i, j) / 255-f_{d} / 255\right\}^{2} / N_{V}}
$$

ここで, $V$ は矩形の枠上に位置する画素の集合， $f(i, j)$ は $V$ に 含まれる各画素の港度值, $N_{V}$ は $V$ に含まれる画素数, $f_{d}$ は $V$ に含まれる全画素の平均濃度を意味する。なお, 定数 255 は， 漫度の最大值である。

以上に述べた(a)から(1)の特徴量は，すべて0から1までの 箐囲内の值に正規化を行い，值が高いほど各々の特徽を影著 に表しているとする.

\section{2 染色体のコーディング}

次に，GA によって進化される集団を構成する各個体の染 色体を定義する．染色体には，課題の解をコーディングする 必要があるが，ここでの解は，ある物体の認識に有効な特徽 量を選択することと，選択された各特徽量の重みを求めるこ とである．本手法では図 5 に示すように，3.1節で述べた 12 種類の各特徵量候補の重みを各々 4 ビットで表現することに する，従って，染色体長は 48 ビットになる.このような染 色体のコーディング方法を採用することによって，特徴量侯 補の選択と各特徵量の重み設定の双方を行うことが可能と なる.すなわち，ある特徵量の重みが 0 の場合は，その特徽 量を使用しないことを意味する，なお，特徽量の学習および 詪識の際は，すべての特徽量候補の重みの総和が 1 となるよ うに, 各特徽量の重みを線形変換する，すなわち，ある特徵 量 $n$ の重み $W_{n}$ は, 次式によって求める。

$$
W_{n}=w_{n} / \sum_{n=1}^{12} w_{n}
$$

ここで, $w_{n}$ は，染色体が表す特徴量 $n$ の 4 ビットによる重み を意味する，なお，GAにおける進化の第 1 世代では，す心゙ ての個体の染色体には，ランダムな重みを設定する.

\section{3 適度度の評価}

欧に，各個体の適応度を評価する，本手法では，ある個体 の染色体情報が表す特徽量候補の重みの組合せが対象物体 の詔識に有効であるほど，その個体には高い適応度を与える。 図 6 は，個体の適応度の評価方法を示す，ます，認識す心゙

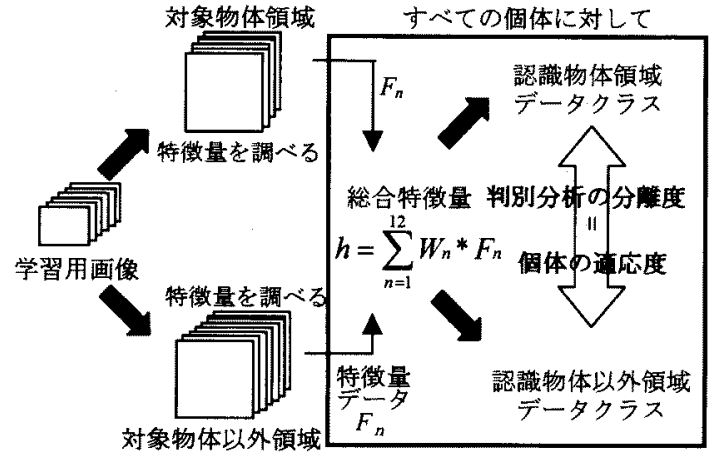

図 6 適応度の評価

Fig.6 Evaluation of fitness

き対象物体を含む学習用画像を複数枚準備し，マウスを用い て，各学習用画像から正確に対象物体領域を，すべて同じサ イズの矩形によって切り出す，そして，各矩形について，3.1 節で述べた 12 種類の特徵量候補の値を求める. 次に, 学習 用画像内から，今度は対象物体を含まない複数の領域をラン ダムに切り出す．この場合，矩形のサイズは，先程对象物体 を切り出した矩形のサイズと同一とする．この作業を各学習 用画像について行い, 対象物体を含まない矩形についても 12 種類の特徴量候補の值を求める，なお，各矩形内で求められ た特徵量候補 $n$ に関する特徴量の値を $F_{n}$ とする. 以上の操 作を GAの前処理として行う

次に, GAの中で, 前処理で得られた各特徽量候補の值 $F_{n}$ と, ある個体の染色体情報から得られた各特徵量候補の重み $W_{n}$ の積を加算した総合特徽量 $h$ を次式によって求める.

$$
h=\sum_{n=1}^{12} F_{n} \cdot W_{n}
$$

そして，対象物体を囲む矩形領域から得られる総合特徵量の 組をクラス A，対象物体以外を囲む矩形領域から得られる総 合特徴量の組をクラス B とし，判別分析法 ${ }^{(18)}$ を用い，これら 2 つのクラスを分離する. 判別分析法によって求められるク ラス分離度が高いほど，その個体の染色体が表す各特徽量の 重みは，認識に有効であると考えることができる，従って， 個体の適応度として，判別分析法によって求められるクラス 分離度を直接用いることにする。

\section{4 進化方法}

GAにおける集団の進化方法には，ランク方式を用いる( ${ }^{(3)}$. 進化の各世代において，集団内の全個体の中で，適応度が上 位 $S \%$ 個体だけを次世代に存続させる. 一方, 適応度が下 位 $(100-S) \%$ の個体は，集団から淘汰する，そして，存続を 許可した上位 $S \%$ の個体閒の交叉によって, 淘汰した個体と 同数の個体を增殖させる.

\section{5 交叉と突然変異}

交叉には，一般的な 2 点交叉法を用いる(1)(4). 交叉の結果， 異なる染色体情報を持つ 2 種類の子供個体が生成されるが， 双方の子供個体の適応度を求め, 高い適応度を持つ子供個体 だけを集団に増殖させる，また，突然変異には，一般的なビ ット反転方式を用いる。 


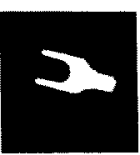

A

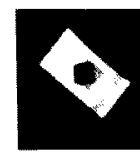

B

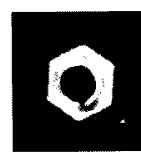

$\mathrm{C}$
図 7 対象物体

Fig.7 Recognition object

表 1 特徴量学習結果

Table 1 learning results of features

\begin{tabular}{|c|c|c|c|c|c|c|}
\hline & 便用特䧱量 & É-ク1 & 庭分橵 & 桿の腹变分数 & 距矆分敏 & \\
\hline & 重好 & 0.18 & 0.04 & 0.65 & 0.13 & \\
\hline & 使用等徽量 & $\begin{array}{l}\text { 曲率分散 } \\
\end{array}$ & $E^{\circ}-72$ & 直角度 & 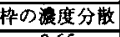 & \\
\hline & 重み & 0.09 & 0.22 & 0.04 & & \\
\hline & 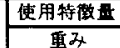 & $\frac{\text { 曲曲分散 }}{0.05}$ & $\frac{\text { エントロピー }}{0.05}$ & $\frac{\mathfrak{K}^{\prime}-ク 3}{0.18}$ & $\frac{\text { 淲度分散 }}{0.05}$ & $\frac{\text { 样の浱度分散 }}{0.67}$ \\
\hline
\end{tabular}

\section{6 終了条件}

以上に述べた遺伝的規則に基づく $\mathrm{GA}$ を適用し, 集団進化 の中で，各世代において最大適応度を持つ個体を抽出する. そして, 最大適応度がある世代の閒, 一定值を保った時点で, 進化が終了したと見なし，この時点で最大適応度を持つ個体 の染色体を解とする.

\section{4. 実験と結果}

以上に述べた手法を用い, 各種の物体について特徵量を学 習し，また，その学習結果を用いて認識実験を行った。

\section{1 実験条件}

対象物体は, 図 7 に示寸 A，B，Cの3 種類とした。 これ らの物体が含まれる対象画像のサイズは $480 \times 640$ 画素であ り，画像内から $100 \times 100$ 画素のサイズの矩形によって物体 領域が切り出される. 3.3 節で述べた対象物体を含まない矩 形領域は, 30 枚の学習用画像内から, 計 300 個所をランダム に切り出した. GA における各パラメータは, 集団内の個体 数 10000 , 次世代一の生存率 $50 \%$, 突然変異率 $0.1 \%$ とし, $\mathrm{GA}$ の終了条件は, 過去 10 世代の最大適応度が一定値を保っ た時点とした。

\section{2 特徵量学習結果}

3 章で述べた手法を用いて，特徵量の学習実験を行った。

$\mathrm{A}, \mathrm{B}, \mathrm{C}$ の各物体について, 特徵量候補の中から認識に有効 と考えられる特徵量の重みを GAによって求めた結果, 最終 的に0より大きい重みが得られた特徴量を表 1 に示す. 物体 の種類に応じて, 異なる特徽量とその重みが設定されている ことが分かる. 図 7 に示した各物体の形状と比較すると, 3.1 節で述べた特徴量候補の中で, 物体 A では, 2 つの突出した 部分の平行な輪郭線部分が(d)ピーク1によって表現され, ま た，大きく窪んだ全体の形状が(i)距離分散によって表現され ている. また, 物体 B では, 長方形の 2 組の平行な輪郭線が (e)ピーク 2 にって表現され, 全体の形状が(a)曲率分散およ び $(\mathrm{g})$ 直角度によって表現されている. 更に, 物体 Cでは, 六 角形を表す 3 組の平行な輪郭線が(f)ピーク 3 によって表現さ れ，中心の穴の部分が(b)エントロピーによって，また，全体 の形状が(a)曲率分散で表現されている. なお，(k)濃度分散お よび(1)矩形枠上の浱度分散は, 矩形内全体の特徽を表現して

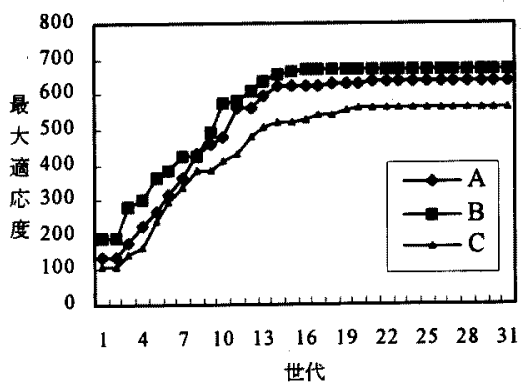

図 8 世代数と最大適応度との関倸

Fig. 8 Relation between generation and the maximum fitness

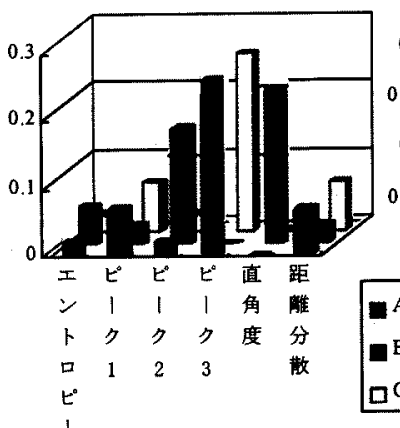

第 1 世代

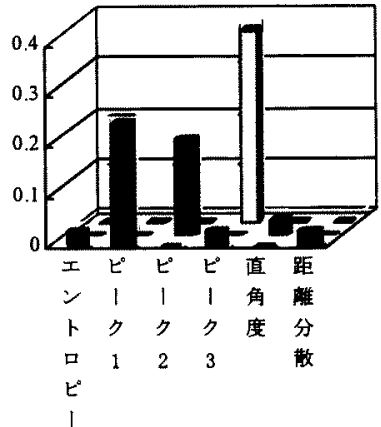

第 10 世代

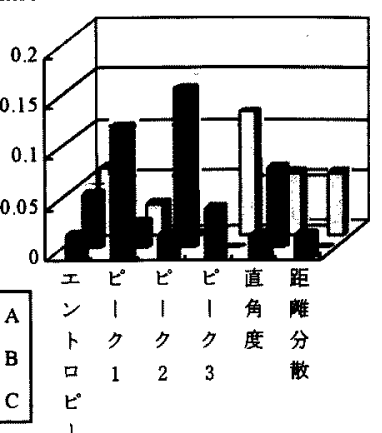

第 5 世代

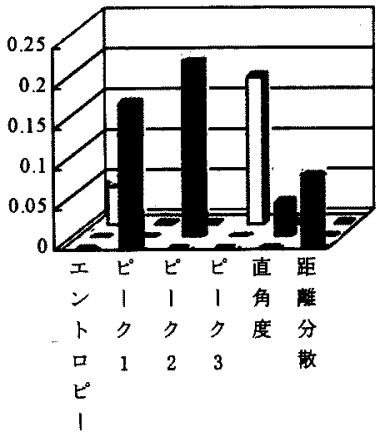

第 20 世代
図 9 世代数と最大適応度の染色体情報との関係 Fig. 9 Relation between generation and chromosome information of the maximum fitness

おり，3.1 節で述べたように, 後述する認識処理の際, 證諗 識の回避に有効に働く特徽量であると考えられる. 以上に述 べた特徴量の学習結果は，我々が A， B，Cの各々の物体か ら視覚的に印象を受ける特街と関連性が哚いと考えられる. また，同一の物体について数回の学習を行ったところ，ほぼ 同様の学習結果が得られたことから，GA による特徽量学習 は安定に㗢いているといえる。

\section{3 進化過程}

$\mathrm{A}, \mathrm{B}, \mathrm{C}$ の各物体について, 特徵量の学習が完了するまで の世代数と最大適応度の関保を図 8 に示す.世代の進行に伴 って最大適応度は徐々に増加し, 30 世代程度で進化が完了し ている.

次に，世代の進行に伴って，最大適応度を持つ染色体が表 現する各特徽量の重みが推移する様子を図 9 に示す、ここで 
表 2 認識率

Table 2 Recognition rate

\begin{tabular}{c|c|c|c|c}
\hline & 物体 & 実験枚数 & 成功枚数 & 認識成功率 \\
\hline \multirow{3}{*}{ 学習用画像 } & $\mathrm{A}$ & 30 & 30 & $100 \%$ \\
\cline { 2 - 5 } & $\mathrm{B}$ & 30 & 29 & $96.7 \%$ \\
\cline { 2 - 5 } & $\mathrm{C}$ & 30 & 29 & $96.7 \%$ \\
\hline \multirow{3}{*}{ 非学習用画像 } & $\mathrm{A}$ & 70 & 66 & $94.3 \%$ \\
\cline { 2 - 5 } & $\mathrm{B}$ & 70 & 64 & $91.4 \%$ \\
\cline { 2 - 5 } & $\mathrm{C}$ & 70 & 61 & $87.1 \%$ \\
\hline
\end{tabular}

は, 各々の物体について，学習によって選ばれた主な特徽量 を 2 づつ, 計 6 種類の特徵量の重みだけを参考として提示 している. 第 1 世代では, 各特徵量にランダムな重みを与え ているため, 最終的な特徴量の学習結果とは大きく異なる重 みのバランスとなっている. 第 5 世代では, 徐々に特定の特 徵量に重みが集中し，第 10 世代から第 20 世代にかけて，ほ ぼ完全に特定の特徴量に重みが収束していることがわかる. なお，図 9 に示さなかった他の特徴量についても，世代の進 行に伴って同様な収束傾向が見られた．以上の結果から，提 案した手法によって, 特徴量の重みが自動的かつ効率的に設 定されているといえる.

\section{4 物体の認識結果}

次に, 4.2 節で述べた特徴量の学習結果を用い, 学習用画 像 30 枚を含む合計 100 枚の濃淡画像の中から，A，B，Cの 各物体を認識する, 寸なわち, 各々の物体を画像内から探し 出寸実験を行った. 各々の画像には, 3 種類の物体とともに, 他の物体も含まれている．認識方法としては，画像内におい て $100 \times 100$ 画素の矩形を 10 画素ステップで逐次移動させ, 各々の位置において求められる矩形内の特徵量と学習結果 として得られた各特徵量の重みから(8)式に示した総合特徵 量を求めた後, 画像内において総合特徵量が最大值を記録し た位置を検出するという，簡便な手法を用いた．認識の正誤 に関する判定基準としては，対象物体が矩形によって正確に 切り出された場合だけを成功とみなした. なお，本実験では， 同一の物体が複数存在する場合，あるいは対象物体が画像内 に存在しない場合は対象外とした．提案手法では，総合特徴 量が最大值を記録した画素位置を対象物体の位置として認 識しているので，同一の対象物体が複数個存在している場合 は，最も特徴量が一致した唯一の物体しか認識できない．ま た, 対象物体が画像内に存在しない場合は, 特徴量が最も類 似した他の物体を抽出する。このような場合については，総 合特徴量に闌值処理を施すことによって対応可能であると 考えられるが，今後検討が必要である.

表 2 に認識率を示す，学習用画像に関する認識率は，物体 A が $100 \%$ ，物体 B が $96.7 \%$ ，物体 C が $96.7 \%$ となった. 物 体Aに関しては，す心゙ての画像について認識が成功し，物体

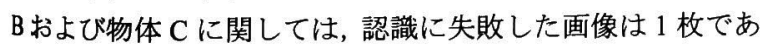
った. この場合, すべての物体に関する平均認識率は, $97.8 \%$ となった. 一方, 非学習用画像の 70 枚に関する認識率は, 物体 A が $94.3 \%$ ，物体 B が $91.4 \%$ ，物体 C が $87.1 \%$ となっ た.この場合，すべての物体に関する平均認識率は，90.9\% となった，以上の結果から，各々の物体について，比較的安

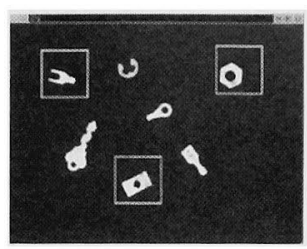

(a)

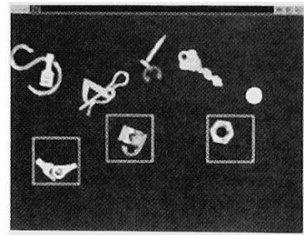

(c)

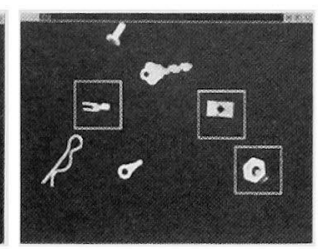

(b)

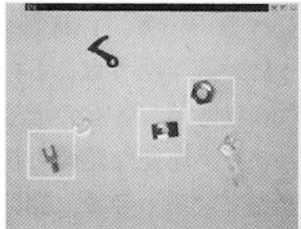

(d)
図 10 認識結果

Fig.10 Examples of recognized objects

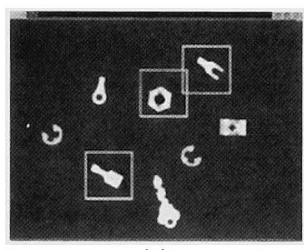

(a)

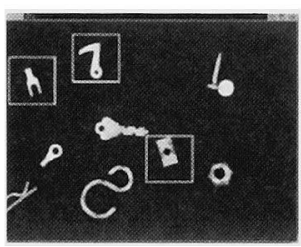

(b)
図 11 認識結果 (失敗例)

Fig.11 Examples of recognized objects (failed case) 定な認識結果が得られたといえる.

次に, 非学習用画像に対して認識処理を行った結果例を図 10 に示寸. 画像内には, 対象物体にとって, 背景ノイズとな る物体がいくつか存在しているが，目的とする物体を正しく 認識している. 図 10(b)では, 図7に示した画像と比較して, 物体 $\mathrm{A}$ および物体 $\mathrm{C}$ の 3 次元的な姿勢が変化しているが, 各々の物体が正しく認識されている，また，図 10(c)では, 対象物体が他の物体と重なり合っているが, 正しく認識され ている.これは，本手法では，対象物体の全体形状を表す特 徵量が学習されるため, 画像内でこのような特徵量が保持さ れている限り, 物体の 3 次元的な姿勢の変化や重なり合いの 影響を比較的受け難いからだと考えられる. 更に, 図 10(d) では, 学習用画像と比較すると, 背景の濃度が大きく異なっ ているが，やはり正しい認識が行われた。これは，本手法で 用いている多くのエッジに基づく特徴量は，画像のコントラ スト変化の影響を比較的受け難いからだと考えられる. 一方 図 11 は, 非学習用画像に対して認識に失敗した例を示す. 図 11(a)では物体 B を他の物体として, また, 図 11(b)では物 体 C を他の物体として誤認識している.これは，赛験に簡易 的な天井照明を用いたため，各々の物体の姿勢によっては， エッジ部分が欠落し，正確な特徵量が計測できなかったこと が原因と考えられる.

今回は, 認識対象以外の物体が背景ノイズとなる環境下で 実験を行ったが, 背景が更に複雑になった場合は, 特徴量候 補の追加などが必要となる可能性もあり，この点は今後の検 討課題である．また，色彩情報を用いることで，より複雑な 背景や多種の物体に対応できる可能性があると考えられる

電学論C, 122 巻 6 号, 平成 14 年 
ため，今後，カラー画像の利用も検討する必要がある.

\section{5 処理時間}

特徵量の学習に要する平均処理時間は，1 種類の物体につ いて, 処理系に Celeron $(541 \mathrm{MH} \mathrm{z})$ を用いて 68 秒であった. 本手法では, 特徴量学習に GA を用いるため, 多くの処理時 間を要している.しかし，特徵量の学習は，オフラインで行 われるため, 多少の時間を要しても大きな問題は発生しない と考えられる.一方, 1 種類の物体に関する認識時間は 30 秒であった. 本手法では, 4.4 節で述べたように, 矩形の位 置を逐次移動させ, 各々の矩形内において特徽量の算出処理 を行うという，簡便な認識方法を用いているため，処理時間 を多く要している. 今後, 認識処理の高速化のため, 物体の 探索にも GA を適用する方法等について検討する必要がある.

\section{5. まとめ}

物体の認識に有効な画像特徵量を GA によって適応的に選 択し，選択された特徴量を用いて画像内から目的とする物体 を探索する手法を提案した. 各種の物体の特徵を表現する上 で重要と考えられる 12 種類の画像特徴量候補の重みを個体 の染色体としてコーディングし，対象物体とシーンの他所と の画像特徵量の相違に基づいて, 判別分析法を用いて各個体 の適応度を求めた．提案手法によって 3 種類の物体について 特徵量を学習した結果, 各々の物体から視覚的に受ける印象 と類似性の高い特徵量について，大きな重みが自動的に設定 された。 また，学習された特徵量を用いて各々の物体の認識 実験を行った結果，学習用画像では平均で $97.8 \%$, 非学習用 画像でも平均で $90.9 \%$ の認識率を得ることができた。

本手法では，逐次探索によって物体の位置を検出している ため, 認識に多くの処理時閒を要している，今後, 物体の位 置をより効率的に求めるために, 認識処理においても GA を 適用するなど，高速化手法について検討する必要がある．ま た，環境変化に対してより頑強な認識を実現するためには， 特徽量候補の種類と内容について更に検討する必要がある.

\section{謝辞}

本研究は, ソフトピアジャパン地域結集型研究開発事業 (JST)の支援によって行われた.

(平成 13 年 6 月 26 日受付, 平成 14 年 2 月 12 日再受付)

\section{文献}

（1）安居院猛, 長尾智晴: “ジェネティックアルゴリズム”, 第 1 章, 昭晃堂(1993).

(2) 北野宏明：“遺伝的アルゴリズム”, 人工知能学会誌, Vol.7,No.5,pp.26-37(1992).

(3) J.H.Holland : "Adaptation in Natural and Artificial Systems", The Univ. Michigan Press (1975)

(4) D.E.Goldberg : "Genetic Algorithm in Search Optimization and Machine Learning", Addison Wesley (1989).

(5) W.M.Silver : "Normalized Correlation Search in Alignment, Gauging, and Inspection ", SPIE Vol.755 Image Pattern Recognition : Algorithm Implementations, Techniques and

Technology, pp.23 -34 (1987).

(6) Jaun Pedro Secilla and Nariciso Garcia : "Template Location in Noisy Pictures", Signal Processing, No.14, pp.347-361 (1988).

(7) 尾上守夫 : “画像処理ハンドブック”, 昭晃堂, pp.303-304 (1987).

(8) B.K.P Horn and K. Ikeuchi : "The Mechanical Manipulation of Randomly Oriented Parts", Scientific American, Vol.251, No.2, pp.100-111 (1984).

(9) W.A.Perkins : "Model-based Vision System for Scene Containing Multi Parts", Proc. 5th International Joint Conference on Artificial Intelligence, pp.678-684 (1977).

(10) 山根定章, 泉正夫, 福永邦雄 : “モデルベースに基づく物体 の位置・姿勢推定”，信学論(D-II), Vol.J79-D-II, No.2, pp.165-173 (1996).

(11) 恩田寿和, 庭川誠, 藤原信行, 清家綾子 : “モデルベースト マッチング法を用いた鋳造部品の視覚位置決め”, 電学論, Vol.119-D, No.1, pp.14-20 (1999).

(12) 谷内田正彦, 白井良明, “パターン情報処理”, オーム社(1996)

(13) 谷口慶治(編), “画像処理工学 応用編”, 共立出版(1996).

(14) 竹村淳, 伊藤正安: “医用超音波画像における生体組織抽出 のための識別関数の自動選択”, 電学論, Vol.118-C, No.11, pp.1596-1602 (1998).

（15）森俊二, 坂倉栂子, “画像処理の基礎 [ II ]”, オーム社 (1990).

(16) 谷口慶治(編), “画像処理工学 基硞編”, 共立出版 (1996).

(17) 村上伸一, “画像処理工学”, 東京電機大学出版局(1996).

(18) N.Otsu : "A Threshold Selection Method from Gray-level Histograms", IEEE Trans. on SMC, Vol.9, No.1, pp62-66 (1979).

(19) A.Rosenfeld and M.Thurston : "Edge and Curve Detection for Visual Scene Analysis", IEEE Trans. on Computer., Vol.20, No.5, pp.562-569 (1971).

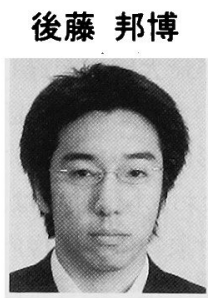

斎藤 文彦

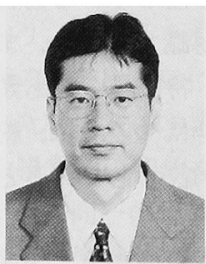

山本 和彦

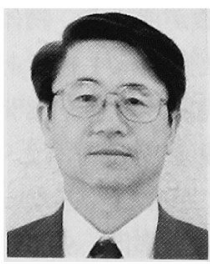

(学生員) 2001 年 3 月岐阜大学工学部応 用情報学科卒業. 現在, 同大大学院工学 研究科博士前期課程在学中. 遺伝的アル ゴリズム，画像処理の研究に従事.

(正員) 1981 年慶大·工・数理卒. 同年 日本 IBM 入社. 1995 年日立製作所入社. 1998 年岩手県立大学助教授. 1999 年岐帛 大学工学部応用情報学科助教授. 博士(情 報科学, 工学). マシンビジョン，視覚情 報処理の研究に従事. 精密工学会, 電子 情報通信学会，画像電子学会等会員。

(正員) 1969 年 3 月東京電機大学工学部 卒業. 1971 年同大大学院修士修了. 同年, 電子技術総合研究所入所. 1986 年通産省 電子技術総合研究所知能情報部画像研究 室室長. 1996 年加現在岐阜大学工学部 応用情報学科教授. 主に, 画像解析, パ夕 一ン認識の研究に従事. 工学博士. 